\title{
A comprehensive study of the potential phytomedicinal use and toxicity of invasive Tithonia species in South Africa
}

\author{
Aitebiremen Gift Omokhua ${ }^{1,2}$, Muna Ali Abdalla ${ }^{3 *}$, Johannes Van Staden ${ }^{2}$ and Lyndy Joy McGaw ${ }^{1}$
}

\begin{abstract}
Background: Tithonia diversifolia and T. rotundifolia belong to the Asteraceae family and are native to Mexico and Central America. These plants have become invasive in parts of tropical Africa and Asia where they have become an ecological, agricultural and economic burden. Tithonia diversifolia is exploited by locals in its native and most parts of its invasive range as a source of medicines; however, T. rotundifolia is only used for medicinal purposes in one country in the native range (Venezuela) and none in the invasive range. Although $T$. diversifolia has been studied for different biological activities, little or no attention has been given to T. rotundifolia. This study compared the antimicrobial activity, phytochemistry, identification of bioactive compound(s) and toxicity levels of different leaf extracts and fractions of $T$. diversifolia and T. rotundifolia.
\end{abstract}

Methods: Antimicrobial activity was evaluated against seven pathogenic bacteria, four non-pathogenic Mycobacterium species and three fungal species using serial microdilution assays. Phytochemical contents were determined through standard methods of analysis. UPLC/MS was used to analyse the fractions to identify possible bioactive compounds that may be responsible for bioactivity, while toxicity tests were carried out using the colorimetric MTT assay and the Ames test.

Results: Both species had a range of antimicrobial activity against bacterial, mycobacterial and fungal species. However, T. rotundifolia displayed better activity against most of the strains tested with minimum inhibitory concentration values ranging between 0.01 and $0.07 \mathrm{mg} / \mathrm{ml}$. Both species were rich in phenolics, flavonoids and tannins. Tagitinin A was identified as the main compound present in both species, and this compound may be responsible for the antimicrobial activity displayed. Toxicity tests showed that $T$. diversifolia was cytotoxic at concentrations used in this study, while T. rotundifolia was not. Both species did not show any mutagenic/ genotoxic effects.

Conclusion: The above results suggest that both species may be further developed as a source of antimicrobials for the treatment of infections caused by opportunistic pathogens. They may also serve as alternatives to highly exploited plant species with the same medicinal properties. However, T. diversifolia should be used with caution as it may be toxic.

Keywords: Alien, Invasive, Phytochemical, Antimicrobial, Selectivity index, Toxicity, Genotoxicity, South Africa

\footnotetext{
* Correspondence: munalsamahoni@yahoo.com

${ }^{3}$ Deparment of Food Science and Technology, Faculty of Agriculture,

University of Khartoum, 13314 Khartoum North, Sudan

Full list of author information is available at the end of the article
}

(c) The Author(s). 2018 Open Access This article is distributed under the terms of the Creative Commons Attribution 4.0 International License (http://creativecommons.org/licenses/by/4.0/), which permits unrestricted use, distribution, and reproduction in any medium, provided you give appropriate credit to the original author(s) and the source, provide a link to the Creative Commons license, and indicate if changes were made. The Creative Commons Public Domain Dedication waiver (http://creativecommons.org/publicdomain/zero/1.0/) applies to the data made available in this article, unless otherwise stated. 


\section{Background}

The genus Tithonia, belonging to the family Asteraceae, comprises eleven species, namely Tithonia excelsa, $T$. playlepsis, T. fruticosa, T. tagitiflora, T. speciosa, T. scaberrima, T. glaberrima, T. ovata, T. tubiformis, T. diversifolia and T. rotundifolia. These species are of Mexican, Central American and Cuban origin [1-3]. However, species such as $T$. diversifolia and $T$. rotundifolia are now found in most parts of the world including Asia and Africa where they have become invasive [4-7]. The two species were introduced as ornamental plants into South Africa in the early 1900s [5]. Tithonia diversifolia, which is the most common in West Africa, was thought to have been introduced into the region through Zea mays importation from Israel in the late 1970s [8]. Both species are aggressive in nature and can grow from cut stems and seeds that fall on the soil during the flowering season and are able to sprout whenever the conditions become favourable. They colonise agricultural lands, abandoned sites, roadsides, railways, waterways and plantations (personal observation). In South Africa, $T$. diversifolia is invasive in the regions of Limpopo, Mpumalanga and along coastal regions of KwaZulu-Natal, while $T$. rotundifolia is invasive in the Gauteng, Mpumalanga, Limpopo and North West provinces [9]. Both species are viewed as environmental and ecological weeds in South Africa because of their allelopathic properties with the ability to compete with native vegetation for light and space $[9,10]$. Due to their negative impacts, the two species have been declared category 1 weeds by The National Environment Management and Biodiversity Act [11]. Control measures such as chemical, mechanical and biological methods are applied to help reduce the spread of these weeds. Although investigations on biological control of these weeds using insects are currently in progress, some insects that feed on $T$. diversifolia do not feed on $T$. rotundifolia. Reasons for this are not known (personal communication with Simelane, ARC-PPRI Pretoria).

Tithonia diversifolia is exploited as a source of medicine in its native and most parts of its invasive regions to treat one or more ailment. The weed is used in Venezuela to treat abscesses [12]; in Mexico for malaria, hematomas and muscular pain [13]; in India for wounds and skin infections [14, 15]; in Taiwan for diabetes [16]; in Kenya for malaria and as an antidote for snake bite and to treat ectoparasites in cattle and to improve appetite [17]; in Uganda for microbial infection in sexual organs [18]; and in Nigeria for malaria [19]. The species is also used for poultry feed, as pesticides, compost for soil improvement and for bioremediation in Nigeria, Malawi, Kenya, Uganda and Zimbabwe [20-23]. Several workers have reported the extracts of the weed to possess antiviral, antidiabetic, anthelmintic, anti-inflammatory, antispasmodic, antiproliferation and antimalarial activities as well as analgesic properties [24-29]. Antibacterial and antifungal activity have also been investigated [30], however, there is no existing report on antimycobacterial activity. Phytochemicals such as phenolics, flavonoids, tannins, alkaloids, saponins and cardiac glycosides have been detected in the species [31]. A plethora of compounds which include sesquiterpenoids, diterpenoids and flavonoids have been isolated [32].

Tithonia rotundifolia has only been reported to be used as a source of medicine to treat fever in Venezuela [12]. Some compounds, including germacranolides, eudesmanolides and flavonoids have been isolated from this weed [32]. However, information on the biological activities of extracts and fractions and phytochemical quantification of this weed is scarce or non-existent. This study investigates and compares the antimicrobial activity of extracts and fractions of $T$. diversifolia and $T$. rotundifolia against selected pathogenic organisms and non-tuberculous mycobacteria, quantification of phytochemicals and identification of the bioactive compound(s) and toxicity levels.

\section{Methods}

\section{Microbial strains}

Microbial strains used in this study were Escherichia coli (ATCC 25922), Enterococcus faecalis (ATCC 29212), Salmonella Typhimurium (ATCC 700720), Pseudomonas aeruginosa (ATCC 27853), Staphylococcus aureus (ATCC 29213), Salmonella Dublin (ATCC 15480), Mycobacterium smegmatis (ATCC 1441), M. aurum (NCTC 10437), M. fortuitum (ATCC 6841) and BCG M. bovis Pasteur strain (P1172). Klebsiella pneumoniae was isolated from commercial chicken eggs [33]. Aspergillus fumigatus was isolated from a chicken with systemic mycosis, Cryptococcus neoformans from a cheetah and Candida albicans from a Gouldian finch.

\section{Plant collection and sample preparation}

The leaves of $T$. diversifolia were collected from Umkomaas, south coast of KwaZulu-Natal, while the leaves of T. rotundifolia were collected from Pretoria North, Gauteng, in South Africa. Voucher specimens (Coll. 6 PRU 123728, Tithonia diversifolia, and Coll. 1 PRU 123725, Tithonia rotundifolia) were identified with help from the herbarium curator Mrs. Elsa van Wyk and deposited at the H.G.W.J. Schweickerdt Herbarium, University of Pretoria. Leaves of both plants were placed in the drying room of the Department of Paraclinical Sciences to dry, ground to powder and stored in sealed glass jars while preparing for experiments. 


\section{Preparation of plant extracts and fractions for antimicrobial and toxicity assays}

From each powdered sample, $4 \mathrm{~g}$ was weighed into centrifuge tubes, $40 \mathrm{ml}$ of $70 \%$ ethanol (EtOH), hot distilled water, acetone, dichloromethane (DCM) and $50 \%$ methanol $(\mathrm{MeOH})$ were added separately to each aliquot of powder. The mixtures were centrifuged at $300 \mathrm{x} \mathrm{g}$ for $10 \mathrm{~min}$ and filtered through Whatman No. 1 filter paper. The resultant extracts were transferred into pre-weighed labelled glass vials and the procedure was repeated twice on the marc to exhaustively extract plant material. Resultant extracts were placed under a stream of air to dry completely and stored in a dark room at $4{ }^{\circ} \mathrm{C}$ while preparing for the experiment. For fractionation $30 \mathrm{~g}$ of each plant material was extracted with absolute $\mathrm{MeOH}$ and allowed to dry. The dried extracts were fractionated with a separating funnel using hexane, chloroform, ethyl acetate and butanol. Various fractions were dried and used for the experiments.

\section{Extraction of plant material for phytochemical determination}

Ten milligrams of $50 \% \mathrm{MeOH}$ was added to $0.1 \mathrm{~g}$ dried plant samples weighed into a $50 \mathrm{ml}$ centrifuge tube. The mixture was stirred using a spatula and centrifuged for $10 \mathrm{~min}$ at $300 \mathrm{x} \mathrm{g}$. After centrifugation the mixture was filtered through Whatman No. 1 filter paper and the resultant extracts were used immediately to determine the phytochemicals in focus to prevent metabolite deterioration or decomposition.

\section{Antimicrobial screening}

\section{Culturing bacterial and fungal strains}

Bacterial stocks were maintained on Mueller-Hinton $(\mathrm{MH})$ agar while fungi were maintained on Sabouraud Dextrose (SD) agar. The agar were sterilized by autoclaving, poured into Petri dishes and allowed to gel. The plates were allowed to cool overnight and the stock bacterial and fungal strains were streaked and sub-cultured on the plates. The inoculated bacterial plates were incubated for $24 \mathrm{~h}$ at $37{ }^{\circ} \mathrm{C}$ while fungal plates were incubated for $48 \mathrm{~h}$ at $30{ }^{\circ} \mathrm{C}$ to allow the colonies to develop. Mycobacterium strains were cultured adopting the method of McGaw et al. [34] and maintained on Löwenstein-Jensen agar slants, supplemented with glycerol. Prepared cultures were stored at $4{ }^{\circ} \mathrm{C}$ for maintenance.

\section{In vitro microdilution assay}

The antibacterial, antifungal and antimycobacterial assays were carried out through the serial microdilution method in a 96-well microplates described by Eloff and Masoko et al. [35, 36]. To prepare the cultures, a single colony of each bacterial strain (Klebsiella pneumoniae, Pseudomonas aeruginosa, Enterococcus faecalis, Escherichia coli, Staphylococcus aureus, Salmonella Typhimurium and $S$. Dublin) was inoculated from agar plates into sterilized $\mathrm{MH}$ broth in sterile McCartney bottles incubated at $37^{\circ} \mathrm{C}$ in an incubator with an orbital shaker for between 12 and 18 h. Aspergillus fumigatus Cryptococcus neoformans and Candida albicans cultures were prepared by inoculating each fungal species in sterilized SD broth in sterile McCartney bottles and incubating at $30^{\circ}$ $\mathrm{C}$ in an incubator with an orbital shaker for $24 \mathrm{~h}$ for $C$. albicans and $72 \mathrm{~h}$ for $C$. neoformans and A. fumigatus. Each culture was diluted in fresh MH/SD broth and the absorbance was measured at a wavelength of $560 \mathrm{~nm}$ using a microplate reader, compared to a McFarland standard No. 1, and used for the screening. To each well of a sterile 96-well microplate, $100 \mu \mathrm{l}$ of sterile water was added followed by the resuspended plant extracts $(10 \mathrm{mg} / \mathrm{ml}$ in $50 \% \mathrm{MeOH}$ for the $50 \% \mathrm{MeOH}$ extract, distilled water for hot water extract and acetone for the other organic solvent extracts and fractions) only on the first row. From the first row the mixture was serially diluted two-fold downwards (column 1-12: A to H). One hundred $\mu \mathrm{l}$ of the diluted culture were added to each well of the microplates afterwards. Similarly, $100 \mu \mathrm{l}$ of $2 \mathrm{mg} / \mathrm{ml}$ gentamicin and Amphotericin B used as positive controls and $50 \% \mathrm{MeOH}$, distilled water, and acetone as negative controls were serially diluted. Also, a plate containing only sterile water and bacteria or fungi was also prepared as a guide for reading the minimum inhibitory concentrations (MIC). The microplates were incubated at $37{ }^{\circ} \mathrm{C}$ for bacteria and $30{ }^{\circ} \mathrm{C}$ for fungi for $24 \mathrm{~h}$. To all wells of the incubated microplates, $40 \mu \mathrm{l}$ of $0.2 \mathrm{mg} / \mathrm{ml} \mathrm{p}$-iodonitrotetrazolium chloride (INT) were added to the bacterial and $50 \mu \mathrm{l}$ to the fungal plates. The last well with clear inhibition of bacterial or fungal growth as shown by a decrease in colour change of the INT was recorded as the MIC after $1 \mathrm{~h}$ of further incubation for bacteria and 24 and $48 \mathrm{~h}$ for fungi. The experiment was repeated twice with three replicates in each assay.

For the mycobacterial strains, cultures of M. smegmatis, M. aurum, M. fortuitum and M. bovis were prepared by mixing a few microbial colonies of each strain with sterile distilled water to attain a concentration of cells compared to a McFarland No. 1 solution. Cell suspensions were diluted with freshly prepared Middlebrook 7H9 broth supplemented with $10 \%$ oleic acid, albumin, dextrose, and catalase (OADC) to obtain a final inoculum density of approximately $4 \times 10^{7} \mathrm{cfu} / \mathrm{ml}$. Streptomycin and rifampicin were used as positive controls and sterile water, acetone and $50 \% \mathrm{MeOH}$ as negative controls. The microdilution assay as described by Eloff [35] was applied to obtain the MICs. 


\section{Phytochemical determination}

Phytochemical detection Phytochemicals were qualitatively detected in the plant extracts using standard procedures for phenolics, flavonoids and tannins [37-39], alkaloids [9, 40] and saponins [41].

Phytochemical quantification Total phenolics, total flavonoids, flavonol and hydrolysable tannin contents were quantitatively determined following standard methods using freshly prepared $50 \% \mathrm{MeOH}$ extracts. Following Folin-Ciocalteu (Folin-C) method [42] with some modifications total phenolic compositions of the plant extracts were evaluated. From each freshly prepared $50 \% \mathrm{MeOH}$ plant extract $50 \mu \mathrm{l}$ was transferred into test tubes (5 test tube replicates for each extract), $950 \mu \mathrm{l}$ of sterile distilled water was added followed by the addition of $500 \mu \mathrm{l}$ of $1 \mathrm{~N}$ Folin-C reagent and $2.5 \mathrm{ml}$ of $2 \%$ sodium carbonate $\left(\mathrm{NaCO}_{3}\right)$ in the dark. Different concentrations of gallic acid ranging from 0 to $150 \mathrm{mg} /$ $\mathrm{ml}$ ) were prepared and used as the standard. Also, a blank containing $50 \% \mathrm{MeOH}$ in place of the plant extracts was prepared. The test tubes containing the mixtures were incubated at room temperature for $40 \mathrm{~min}$, and $200 \mu \mathrm{l}$ of the reacted mixtures were immediately transferred into 96-well plates and a microplate reader was used to measure the absorbance at $725 \mathrm{~nm}$. Total phenolics were expressed as $\mathrm{mg}$ gallic acid equivalents (GAE) per gram dry weight.

The butanol- $\mathrm{HCl}$ assay as described by Makkar [42] was used to determine hydrolysable tannin content of the plant extracts. Five hundred microliters of plant extracts were aliquoted into test tubes and diluted to $10 \mathrm{ml}$ with $50 \% \mathrm{MeOH}$. Three $\mathrm{mg}$ of butanol $/ \mathrm{HCl}(95 /$ $5 \%$ ) reagent was added followed by $100 \mu \mathrm{l}$ of $2 \%$ ferric ammonium sulphate in $2 \mathrm{~N} \mathrm{HCl}$. The test tubes were loosely covered and heated for $50 \mathrm{~min}$ in a boiling water bath. After the test tubes were allowed to cool at room temperature the absorbance was read at $550 \mathrm{~nm}$ including an unheated mixture used as blank.

Adopting the method described by Abdel-Hameed et al. [43] with some modification, the total flavonoid content of the plant extracts was determined using the aluminium chloride. One hundred $\mu \mathrm{l}$ of plant extract was mixed with $100 \mu \mathrm{l}$ of $20 \%$ aluminium chloride $\left(\mathrm{AlCl}_{3}\right)$ and 2 drops of glacial acetic acid. The mixture was diluted to $3000 \mu \mathrm{l}$ with $50 \% \mathrm{MeOH}$. Blank samples were prepared without $\mathrm{AlCl}_{3}$, and a standard curve was prepared using catechin (concentration between 0 and $150 \mathrm{mg} / \mathrm{ml}$ ) in $\mathrm{MeOH}$. Absorbance was read at $415 \mathrm{~nm}$ after $40 \mathrm{~min}$. The total flavonoid content was expressed as $\mathrm{mg}$ catechin equivalent (CE) per gram dry plant material.

With some modification the aluminium chloride method described by Abdel-Hameed et al. [43] was used to quantify the flavonol content. One $\mathrm{ml}$ of $20 \mathrm{mg} / \mathrm{ml}$ of $\mathrm{AlCl}_{3}$ was added to $1 \mathrm{ml}$ of each plant extract in a test tube followed by $3 \mathrm{ml}$ of $50 \mathrm{mg} / \mathrm{ml}$ of sodium ethanoate $\left(\mathrm{CH}_{3} \mathrm{COONa}\right)$. A standard curve was prepared using catechin in $\mathrm{MeOH}$. The mixtures were incubated for $2.5 \mathrm{~h}$ and absorbance was read at $440 \mathrm{~nm}$. Flavonol content was expressed as $\mathrm{mg}$ catechin equivalent per gram of dry plant material.

\section{UPLC/MS detection of active compound(s)}

One milligram $(1 \mathrm{mg} / \mathrm{ml})$ of each fraction of both species was dissolved with $500 \mu \mathrm{l}$ of acetonitrile and $500 \mu \mathrm{l}$ water (UPLC grade) and sonicated for $5 \mathrm{~min}$. From the mixture, $100 \mu \mathrm{l}$ was pipetted into Eppendorf tubes and made up to $1 \mathrm{ml}$ with acetonitrile and water and vortexed for $2 \mathrm{~min}$. From the solution $100 \mu \mathrm{l}$ was transferred into UPLC graded p-vials and made up to $1 \mathrm{ml}$. A blank containing acetonitrile and water was prepared and samples were loaded into the HPLC-HR-ESI-MS (Waters Acquity) Ultra Performance Liquid Chromatography (UPLC ${ }^{\circ}$ ) system hyphenated to a quadrupole-time-of-flight (QTOF) and were analyzed.

\section{Toxicological assays In vitro cytotoxicity assay}

The plant extracts were screened for cytotoxicity against Vero monkey kidney cells using the tetrazolium-based colorimetric (MTT) assay described by Mosmann [44]. The Vero cell line was chosen for the study due to its sensitivity to toxicity, easy to culture and availability and also following its recommendation as a model to detect basal cytotoxicity [45]. Vero cells were grown in Minimal Essential Medium (MEM) supplemented with 0.1\% gentamicin (Virbac) and 5\% foetal calf serum (Highveld Biological). Cells of a subconfluent culture were harvested and centrifuged for $5 \mathrm{~min}$ at $200 \mathrm{x} \mathrm{g}$. followed by resuspension in MEM to attain a $5 \times 10^{4}$ cells $/ \mathrm{ml}$. To each well of a sterile microplate $100 \mu \mathrm{l}$ of cell suspension was pipetted into columns 2 to 11 and only MEM $(200 \mu \mathrm{l})$ in columns 1 and 12 to maintain humidity. The plates were incubated at $37{ }^{\circ} \mathrm{C}$ in a $5 \% \mathrm{CO}_{2}$ incubator for $24 \mathrm{~h}$ to allow the cells to attach and reach the exponential phase of growth. One hundred $\mu \mathrm{l}$ of the extracts at differing concentrations prepared in MEM was added to the plates in quadruplicate. The microtitre plates were further incubated for $48 \mathrm{~h}$ at $37{ }^{\circ} \mathrm{C}$ in a $5 \% \mathrm{CO}_{2}$ incubator with the plant samples. Untreated cells, positive control (doxorubicin chloride, Pfizer Laboratories) and negative controls (acetone, $50 \% \mathrm{MeOH}$ and distilled water) were also included. After incubation for $24 \mathrm{~h}$, the MEM with plant extract was aspirated from the cells and washed with $150 \mu \mathrm{l}$ phosphate buffered saline (PBS, Whitehead Scientific) and replaced with $200 \mu$ of fresh MEM. Following the washing step, $30 \mu \mathrm{l}$ MTT (Sigma, 
stock solution of $5 \mathrm{mg} / \mathrm{ml}$ prepared in PBS) was added to each well and the plates were incubated for a further $4 \mathrm{~h}$ at $37^{\circ} \mathrm{C}$. After incubation with MTT the medium and the MTT in each well were carefully removed, without disturbing the MTT crystals in the wells. The cells were washed with PBS and the MTT formazan crystals were dissolved by adding $50 \mu \mathrm{l}$ DMSO to each well. The plates were shaken gently to allow the MTT solution to dissolve. The amount of MTT reduction was measured immediately by detecting absorbance in a microplate reader at a wavelength of $570 \mathrm{~nm}$ and a reference wavelength of $630 \mathrm{~nm}$. The wells in columns 1 and 12, containing medium and MTT without cells, were used to blank the plate reader. The $\mathrm{LC}_{50}$ value was calculated as the concentration of plant samples resulting in a $50 \%$ reduction of absorbance compared to untreated cells.

\section{In vitro genotoxicity assay}

Genotoxicity of the plant samples was determined by testing the plant samples against $S$. typhimurium strains TA98 (for frameshift mutation) and TA100 (for base-pair mutation) using the plate incorporation assay (Ames test) as described by Maron and Ames [46]. Acetone, DCM and hot water extracts were dissolved initially in 10\% DMSO and later diluted to the required concentrations (5, 0.5 and $0.05 \mathrm{mg} / \mathrm{ml}$ ) under sterile conditions using sterile distilled water to reduce the DMSO concentration to $1 \%$. The plant samples were filter-sterilized and each plant sample was tested against $S$. typhimurium strains TA98 and TA100 $(100 \mu \mathrm{l} /$ plate of a fresh overnight culture prepared by inoculating $100 \mu \mathrm{l}$ stock bacteria in $10 \mathrm{ml}$ Oxoid nutrient broth and incubating for $16 \mathrm{~h}$ at $37^{\circ}$ C) without exogenous metabolic activation. A positive control, 4-nitroquinoline-N-oxide (4-NQO) and negative controls $1 \%$ DMSO and sterilized water were also prepared. The plates were incubated for $48 \mathrm{~h}$ at $37^{\circ}$ $\mathrm{C}$ and colonies were counted manually using a colony counter.

\section{Statistical analysis}

A Student t-test using GENSTAT statistical software, version 14.0 (VSN International Ltd., UK), was used to compare the amount of total phenolics, total flavonoids, flavonol content and hydrolysable tannins of the extracts. Where the test statistics were not significant, no post-hoc tests were done. Finally, a Student t-test was used to analyse cytotoxicity and genotoxicity data.

\section{Results}

Antimicrobial activity

Antibacterial activity

The solvent leaf extracts and fractions of $T$. diversifolia and $T$. rotundifolia exhibited different levels of inhibitory activity (from moderate to very good chosen with reference to Eloff [47] and Sánchez and Kouznetsov [48]) against all tested bacterial strains (Table 1). Ethanol (70\%) and acetone extracts of $T$. diversifolia displayed good activity with MIC of $0.07 \mathrm{mg} / \mathrm{ml}$ against E. faecalis. The hexane and chloroform fractions were very active against $P$. aeruginosa $(0.07 \mathrm{mg} /$ $\mathrm{ml})$. Hot water extract of $T$. rotundifolia showed very good activity against $E$. coli and $S$. Typhimurium with MIC of $0.01 \mathrm{mg} / \mathrm{ml}$ and good activity $(0.07 \mathrm{mg} / \mathrm{ml})$ against E. faecalis, followed by the acetone extract with MIC of $0.03 \mathrm{mg} / \mathrm{ml}$ against E. faecalis, $0.07 \mathrm{mg} /$ $\mathrm{ml}$ against $K$. pneumoniae, S. aureus and S. Typhimurium. The DCM extract showed good activity $(0.07 \mathrm{mg} / \mathrm{ml})$ against $S$. aureus. Activities displayed by the different fractions of $T$. rotundifolia were moderate except for the butanol fraction which showed no inhibitory effect against all tested strains.

\section{Antimycobacterial activity}

The MICs of antimycobacterial activity displayed by both species are presented in Table 2. Although most of the extracts and fractions of $T$. diversifolia displayed weak antimycobacterial activity, the DCM and acetone extracts were moderately active against $M$. aurum while only the acetone extract was moderately active against $M$. bovis BCG. Only the $70 \% \mathrm{EtOH}$ and $50 \% \mathrm{MeOH}$ extracts showed moderate activity against $M$. smegmatis. Among the extracts and fractions of $T$. rotundifolia tested, most of the activities ranged from weak to moderate. However, the DCM and acetone extracts showed good activity $(0.07 \mathrm{mg} / \mathrm{ml})$ against $M$. aurum and $M$. smegmatis and very good activity $(0.03 \mathrm{mg} / \mathrm{ml})$ against $M$. fortuitum. The acetone and ethyl acetate extracts inhibited the growth of $M$. bovis BCG at MIC $0.07 \mathrm{mg} / \mathrm{ml}$, while the DCM extract had MIC of $0.03 \mathrm{mg} / \mathrm{ml}$.

\section{Antifungal activity}

Different levels of antifungal activity were displayed by the solvent extracts and fractions of both species at varying concentrations (Table 3). EtOH (70\%), 50\% $\mathrm{MeOH}$ and acetone extracts only showed good activity against C. neoformans at $48 \mathrm{~h}$ with MIC of $0.07 \mathrm{mg} / \mathrm{ml}$ in all cases. Candida albicans was only inhibited moderately by the acetone extract, while the hexane fraction was very active against $C$. neoformans at $48 \mathrm{~h}$ and good at $72 \mathrm{~h}$ (MIC 0.03 and $0.07 \mathrm{mg} / \mathrm{ml}$ ) and had moderate activity $(0.15 \mathrm{mg} / \mathrm{ml})$ against $A$. fumigatus at $48 \mathrm{~h}$ and $72 \mathrm{~h}$. The chloroform fraction was moderately active only against $C$. neoformans at $48 \mathrm{~h}$. The DCM and acetone extracts of $T$. rotundifolia showed good inhibitory activity against $C$. neoformans $(0.07 \mathrm{mg} / \mathrm{ml})$ and moderate activity $(0.15 \mathrm{mg} / \mathrm{ml})$ at $72 \mathrm{~h}$, and was active against 
Table 1 Antibacterial activity of solvent extracts and fractions of T. diversifolia and T. rotundifolia

\begin{tabular}{|c|c|c|c|c|c|c|c|c|}
\hline \multirow[t]{2}{*}{ Plant species } & \multirow[t]{2}{*}{ Extract/fraction } & \multicolumn{7}{|c|}{$\mathrm{MIC}(\mathrm{mg} / \mathrm{ml})$} \\
\hline & & $\overline{E C}$ & $K p$ & $E f$ & SD & $\mathrm{Pa}$ & $\mathrm{Sa}$ & ST \\
\hline \multirow[t]{9}{*}{ T. diversifolia } & Ethanol & 1.25 & 0.62 & $0.07^{*}$ & 0.31 & 1.25 & 0.31 & 0.62 \\
\hline & Methanol & 0.62 & 0.62 & 0.62 & 0.62 & 1.25 & 0.62 & 0.15 \\
\hline & DCM & 0.31 & 0.15 & 0.31 & 0.31 & 0.31 & 0.62 & 0.62 \\
\hline & Acetone & 0.15 & 0.15 & $0.07^{*}$ & 0.31 & 0.31 & 0.62 & 0.31 \\
\hline & Hot water & 1.25 & 0.62 & 2.5 & 1.25 & 1.25 & 0.15 & 0.62 \\
\hline & Hexane & 1.25 & 0.31 & 0.62 & 0.62 & $0.07^{*}$ & 0.62 & 0.62 \\
\hline & Chloroform & 1.25 & 0.62 & 0.31 & 1.25 & $0.07^{*}$ & 0.15 & 1.25 \\
\hline & Butanol & $>2.5$ & 2.5 & $>2.5$ & $>2.5$ & $>2.5$ & $>2.5$ & $>2.5$ \\
\hline & ETAC & 2.5 & 2.5 & 0.62 & $>2.5$ & 0.15 & 0.31 & 2.5 \\
\hline \multirow[t]{9}{*}{ T. rotundifolia } & Ethanol & 0.31 & 0.15 & 0.31 & 0.62 & 0.62 & $0.07^{*}$ & 0.62 \\
\hline & Methanol & 0.62 & 0.31 & 2.5 & 0.15 & 0.62 & 0.62 & 0.31 \\
\hline & DCM & 0.62 & 0.15 & 0.15 & 0.15 & 0.31 & $0.07^{*}$ & 0.15 \\
\hline & Acetone & 0.31 & $0.07^{*}$ & $0.03 * *$ & 0.31 & 0.31 & $0.07^{*}$ & $0.07^{*}$ \\
\hline & Hot water & $0.01 * *$ & 0.62 & $0.07^{*}$ & 0.62 & 1.25 & 0.31 & $0.01 * *$ \\
\hline & Hexane & 2.5 & 0.62 & 1.25 & 1.25 & 0.62 & 1.25 & 1.25 \\
\hline & Chloroform & 2.5 & $>2.5$ & 1.25 & $>2.5$ & 0.62 & $>2.5$ & $>2.5$ \\
\hline & Butanol & $>2.5$ & $>2.5$ & $>2.5$ & $>2.5$ & $>2.5$ & $>2.5$ & $>2.5$ \\
\hline & ETAC & 0.15 & 1.25 & $>2.5$ & 1.25 & 1.25 & 0.62 & 1.25 \\
\hline $\begin{array}{l}\text { Gent } 2 \mathrm{mg} / \mathrm{ml} \\
\text { (+ve con.) }\end{array}$ & & $0.016^{*}$ & 0.50 & 0.50 & $0.004^{* *}$ & $0.008^{* *}$ & $0.008^{* *}$ & $0.08^{* *}$ \\
\hline
\end{tabular}

DCM dichloromethane, ETAC ethyl acetate fraction, Gent gentamicin, +ve positive control, Ec Escherichia coli, Kp Klebsiella pneumonia, Ef Enterococcus faecalis, SD Salmonella Dublin, Pa Pseudomonas aeruginosa, Sa Staphylococcus aureus, ST Salmonella Typhimurium, T. diversifolia Tithonia diversifolia, T. rotundifolia Tithonia rotundifolia

Values written in bold with no asterisk are considered moderate; Values written in bold with one asterisk are considered active; Values written in bold with two asterisks are considered very active; Values greater than $0.1 \mathrm{mg} / \mathrm{ml}$ but less than $2.5 \mathrm{mg} / \mathrm{ml}$ are considered as weak activity, while values greater than 2.5 are considered not active

C. albicans $(0.07 \mathrm{mg} / \mathrm{ml})$ only at $48 \mathrm{~h}$. Only the acetone extract of $T$. rotundifolia showed good activity $(0.07 \mathrm{mg} /$ $\mathrm{ml}$ ) against $A$. fumigatus, while the DCM extract was moderately active $(0.15 \mathrm{mg} / \mathrm{ml})$. The ethyl acetate fraction also showed moderate activity against $C$. neoformans and C. albicans at $48 \mathrm{~h}$.

\section{Phytochemical determination}

Results from this study showed that both species are rich in phenolics, flavonoids and tannins, while saponins were present in a moderate level, and low amounts of alkaloids were detected in both species (Table 4). Phytochemical quantification showed that $T$. diversifolia and T. rotundifolia are rich in phenolics, flavonoids and tannins (Fig. 1a-d). Phenolics (Fig. 1a) were higher in $T$. diversifolia with a significant difference $\left(t_{2}=4.34\right.$; $P<0.002)$. Although $T$. rotundifolia contained higher amounts of flavonoids (Fig. 1b) and flavonols (Fig. 1c) the differences were not statistically significant $\left(t_{2},=\right.$ $-1.29 ; P=0.234)$ and $\left(\mathrm{t}_{2}=1.14 ; P=0.984\right)$. Tithonia diversifolia was higher in hydrolysable tannin content (Fig. 1d) with a statistical difference $\left(\mathrm{t}_{2}=-2.92 ; P=\right.$ $0.019)$.

\section{UPLC/MS analysis of active fractions}

UPLC-MS-ESI chromatogram of the active chloroform fraction of $T$. diversifolia appointed tagitinin A (molecular weight at $369.19[\mathrm{M}+\mathrm{H}]^{+}$), as the major compound. In addition the Extracted-Ion Chromatogram (EIC) MS of the ethyl acetate fraction of $T$. rotundifolia showed a compound of molecular weight at $369.19[\mathrm{M}+\mathrm{H}]^{+}$ which confirmed it as tagitinin A (Fig. 2).

\section{Toxicity assay}

\section{In vitro cytotoxicity}

The results of the cytotoxicity test carried out on different solvent extracts of $T$. diversifolia and $T$. rotundifolia against Vero monkey kidney cells using the MTT colorimetric assay are presented in Table 5 . The selectivity indexes for bacterial and fungal strains tested are also presented in Tables 6 and 7. In our study we refer to the lethal concentration $\left(\mathrm{LC}_{50}\right)$ below $0.1 \mathrm{mg} / \mathrm{ml}$ to be toxic, and above $0.1 \mathrm{mg} / \mathrm{ml}$ to be less toxic or non-toxic depending on the range. Extracts with selectivity index $\left(\mathrm{LC}_{50} / \mathrm{MIC}\right)$ above 10 are regarded as non-toxic, between 1 and 9 as less toxic and more active, and below 1 as toxic. Results showed that all extracts of $T$. 
Table 2 Antimycobacterial activity of solvent extracts and fractions of T. diversifolia and T. rotundifolia

\begin{tabular}{|c|c|c|c|c|c|}
\hline \multirow[t]{2}{*}{ Plant species } & \multirow[t]{2}{*}{ Extract/fraction } & \multicolumn{4}{|c|}{$\mathrm{MIC}(\mathrm{mg} / \mathrm{ml}$} \\
\hline & & M. aurum & M. bovis & M. fortuitum & M. smegmatis \\
\hline \multirow[t]{9}{*}{ T. diversifolia } & Ethanol & 0.62 & 0.31 & 0.15 & 0.15 \\
\hline & Methanol & 0.31 & 0.62 & 0.31 & 0.15 \\
\hline & DCM & 0.15 & 0.31 & 0.31 & 0.31 \\
\hline & Acetone & 0.15 & 0.15 & 0.62 & 2.5 \\
\hline & Hot water & 0.31 & 0.31 & 0.62 & 0.31 \\
\hline & Hexane & 0.62 & 0.31 & 1.25 & 2.5 \\
\hline & Chloroform & 0.62 & 0.31 & $>2.5$ & $>2.5$ \\
\hline & Butanol & 0.62 & 2.5 & 2.5 & 2.5 \\
\hline & ETAC & 0.62 & 0.62 & 0.31 & 2.5 \\
\hline \multirow[t]{9}{*}{ T. rotundifolia } & Ethanol & 0.62 & 0.62 & 0.62 & 0.62 \\
\hline & Methanol & 1.25 & 0.31 & 1.25 & 0.62 \\
\hline & DCM & $0.07^{*}$ & $0.03^{* *}$ & $0.03^{* *}$ & $0.07^{*}$ \\
\hline & Acetone & $0.07^{*}$ & $0.07^{*}$ & $0.03^{* *}$ & $0.07^{*}$ \\
\hline & Hot water & $>2.5$ & $>2.5$ & 2.5 & 1.25 \\
\hline & Hexane & 0.15 & 0.15 & 0.62 & 0.31 \\
\hline & Chloroform & 2.5 & 0.31 & 0.31 & 0.31 \\
\hline & Butanol & $>2.5$ & $>2.5$ & $>2.5$ & $>2.5$ \\
\hline & ETAC & 0.15 & $0.07^{*}$ & 0.15 & 0.15 \\
\hline Strep (+ve con) & - & $>0.01 * *$ & 0.063 & $>1.0$ & $>0.01$ \\
\hline Rif (+ve con) & - & $>0.01 * *$ & $>1.0$ & 0.063 & $>0.01$ \\
\hline
\end{tabular}

DCM dichloromethane, ETAC ethyl acetate fraction, Strep Streptomycin, Rif Rifampicin, +ve positive control, M. aurum Mycobacterium aurum, M. bovis Mycobacterium bovis, M. fortuitum Mycobacterium fortuitum, M. smegmatis Mycobacterium smegmatis, T. diversifolia Tithonia diversifolia, T. rotundifolia Tithonia rotundifolia

Values written in bold with no asterisk are considered as moderate; Values written in bold with one asterisk are considered active/good; Values written in bold with two asterisks are considered very active/very good; Values greater than $0.1 \mathrm{mg} / \mathrm{ml}$ but less than $2.5 \mathrm{mg} / \mathrm{ml}$ are considered as weak activity, while values greater than 2.5 are considered not active

diversifolia are toxic with $\mathrm{LC}_{50}$ values far lower than $0.1 \mathrm{mg} / \mathrm{ml}$ except the hot water extract with $\mathrm{LC}_{50}$ of $0.275 \mathrm{mg} / \mathrm{ml}$. All extracts of $T$. rotundifolia tested were classified as being less toxic to non-toxic.

\section{In vitro genotoxicity}

Three (3) solvent extracts of $T$. diversifolia and $T$. rotundifolia, namely DCM, acetone and hot water were chosen for the genotoxicity assay. This is because, of the six (6) solvent extracts tested, these three showed a wide spectrum of antimicrobial activity. Results presented in Table 8 showed that none of the plant extracts was genotoxic or mutagenic against the tested strains, although this experiment was carried out without exogenous metabolic activation.

\section{Discussion}

Tithonia diversifolia and $T$. rotundifolia are known invasive weeds listed under category $1 \mathrm{~b}$ of the National Environmental Management and Biodiversity Act [11] in South Africa, due to their negative impact on Agriculture, Ecology and Biodiversity. In a bid to control their spread, different approaches such as mechanical (clearing and digging out the roots), chemical (spraying with herbicides) and biological (use of insects to feed on the plants) control methods have been applied with low success rates. Reasons may be that the mechanical approach is labour intensive, chemical control may result in killing non-target species and, in using biological control which seems to be yielding a better result, there is a possibility that insects feeding on these plants may also be feeding on useful plants which are not the target (except for specialist insects). There is therefore a need to source a better and more sustainable way of controlling the spread of these plants. Regardless of the negative impact caused by these plants, their use in traditional medicine for the treatment of microbial related infections has also been documented [32]. Several studies have been carried out on the bioactivity, phytochemical screening and toxicity of $T$. diversifolia. However such studies on $T$. rotundifolia are scarce. It may not be impossible that good bioactivity possessed by $T$. diversifolia will also be present in $T$. rotundifolia, as several related compounds have been isolated from both species [32]. 
Table 3 Antifungal activity of solvent extracts and fractions of T. diversifolia and T. rotundifolia

\begin{tabular}{|c|c|c|c|c|c|c|c|}
\hline \multirow[t]{3}{*}{ Plant species } & \multirow[t]{3}{*}{ Extract/fraction } & \multicolumn{6}{|c|}{$\mathrm{MIC}(\mathrm{mg} / \mathrm{ml})$} \\
\hline & & \multicolumn{2}{|c|}{ A. fumigatus } & \multicolumn{2}{|c|}{ C. neoformans } & \multicolumn{2}{|c|}{ C. albicans } \\
\hline & & $48 \mathrm{~h}$ & $72 \mathrm{~h}$ & $48 \mathrm{~h}$ & $72 \mathrm{~h}$ & $48 \mathrm{~h}$ & $72 \mathrm{~h}$ \\
\hline \multirow[t]{8}{*}{ T. diversifolia } & Ethanol & 2.5 & 1.25 & $0.07^{*}$ & 2.5 & 2.5 & 2.5 \\
\hline & Methanol & 0.62 & 0.62 & $0.07^{*}$ & 0.62 & 2.5 & 2.5 \\
\hline & DCM & 0.62 & 1.25 & 0.15 & 0.31 & 2.5 & 2.5 \\
\hline & Acetone & 0.15 & 0.31 & $0.07^{*}$ & 0.15 & 0.15 & 0.62 \\
\hline & Hot water & 0.62 & 0.62 & 0.15 & 1.25 & 1.25 & 1.25 \\
\hline & Hexaane & 0.15 & 0.15 & $0.03^{* *}$ & $0.07^{*}$ & 1.25 & 1.25 \\
\hline & Chloroform & 0.31 & 1.25 & 0.15 & 0.31 & 1.25 & 1.25 \\
\hline & ETAC & 2.5 & 2.5 & 0.31 & 1.25 & 0.15 & 0.15 \\
\hline \multirow[t]{9}{*}{ T. rotundifolia } & Ethanol & 1.25 & 1.25 & 0.15 & 0.62 & 1.25 & 1.25 \\
\hline & Methanol & 0.62 & 1.25 & 0.31 & 0.62 & 2.5 & 2.5 \\
\hline & DCM & 0.15 & 1.25 & $0.07^{*}$ & 0.15 & $0.07^{*}$ & 0.15 \\
\hline & Acetone & $0.07^{*}$ & 1.25 & $0.07^{*}$ & 0.15 & $0.07^{*}$ & 0.15 \\
\hline & Hot water & 2.5 & $>2.5$ & 0.62 & 2.5 & $>2.5$ & $>2.5$ \\
\hline & Hexane & 0.31 & 1.25 & 0.62 & 1.25 & 0.15 & 0.15 \\
\hline & Chloroform & $>2.5$ & 0.62 & 1.25 & 1.25 & 0.31 & 0.62 \\
\hline & Butanol & $>2.5$ & $>2.5$ & 0.31 & 0.31 & 1.25 & 1.25 \\
\hline & ETAC & $>2.5$ & 1.25 & 0.15 & 0.62 & 0.15 & 0.62 \\
\hline Amp B (+ve con) & & $0.03^{* *}$ & 0.62 & $0.008^{* *}$ & 0.125 & $0.03^{* *}$ & 0.50 \\
\hline
\end{tabular}

DCM dichloromethane, ETAC ethyl acetate fraction, Amp Amphotericin B, +ve positive control, A. fumigatus Aspergillus fumigatus, C. neoformans Cryptococcus neoformans; C. albicans Candida albicans

Values written in bold with no asterisk are considered as moderate; Values written in bold with one asterisk are considered active; Values written in bold with two asterisks are considered very active; Values greater than $0.1 \mathrm{mg} / \mathrm{ml}$ but less than $2.5 \mathrm{mg} / \mathrm{ml}$ are considered as weak activity, while values greater than $2.5 \mathrm{mg} / \mathrm{ml}$ are considered not active

The current study did not only focus on comparing the antimicrobial activity of extracts and fractions of both species, but also investigated and identified important phytochemicals/compound(s) that may be responsible for such activity, and determined their toxicity levels.

\section{In vitro antimicrobial activity}

Antibacterial/antimycobacterial activity of extracts and fractions of both species

From the results (Tables 1 and 2), the leaf extracts of $T$. diversifolia and T. rotundifolia showed a broad spectrum of antibacterial activity against the strains tested at

Table 4 Phytochemicals qualitatively detected in leaf extracts of T. diversifolia and $T$. rotundifolia

\begin{tabular}{lll}
\hline Phyochemicals & T. diversifolia & T. rotundifolia \\
\hline Phenolics & +++ & +++ \\
Flavonoids & +++ & +++ \\
Tannins & +++ & +++ \\
Alkaloids & + & + \\
Saponins & ++ & ++ \\
\hline
\end{tabular}

$+=$ present

$++=$ moderate

$+++=$ abundant varying concentrations. There was a selective activity of extracts and fractions effective against some strains and not effective against others. The growth of all bacterial strains tested were inhibited by $T$. diversifolia extracts and fractions (weak, moderate and good activities), except for the butanol fraction which did not inhibit the growth of E. coli, E. faecalis, S. Dublin, P. aeruginosa, $S$. aureus and $S$. Typhimurium. Our results agree with the findings of Obafemi et al. [30] for that of the methanolic extract against E. coli and $K$. pneumoniae though they applied the agar well diffusion method. These authors also reported the hexane extract to be effective against E. coli and $K$. pneumoniae, though we only tested the hexane fraction of this plant, which was also effective against these strains. Ethyl acetate fractions were also tested by Obafemi et al. [30] and were found to be effective against E. coli, K. pneumoniae and Pseudomonas aeruginosa, which supports our findings; however, we are reporting the activity displayed as weak. A sesquiterpene lactone isolated by these authors displayed MIC of $0.15 \mathrm{mg} / \mathrm{ml}$ for E. coli, K. pneumoniae and P. aeruginosa respectively. Linthoingambi and Singh [49] tested chloroform, petroleum ether and methanol extracts against E. faecalis, S. aureus, $P$. aeruginosa and E. coli and reported a weak activity of $6.25 \mathrm{mg} / \mathrm{ml}$ for the 

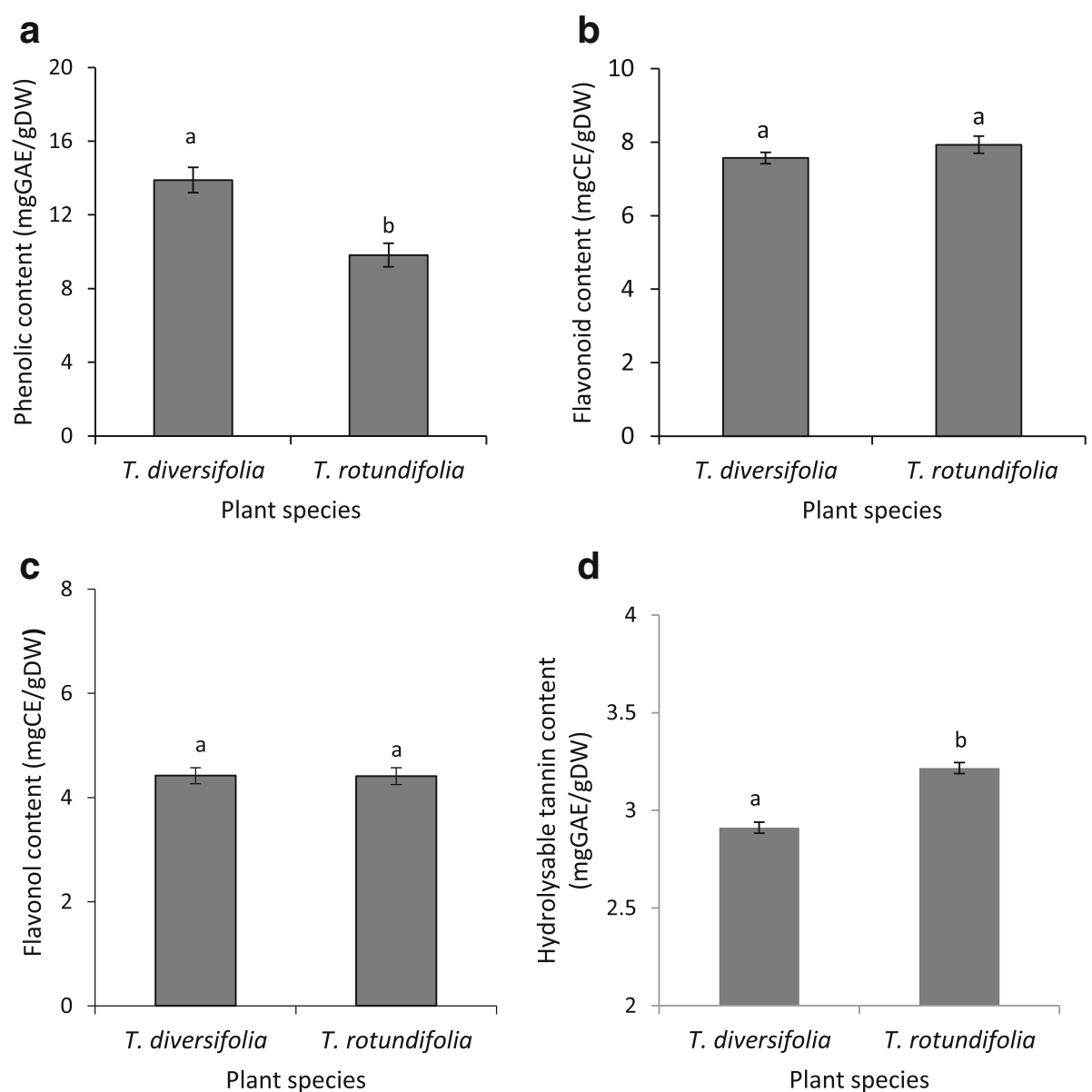

Fig. 1 (a) Total phenolic content, as gallic acid equivalents, quantified in the leaves of Tithonia diversifolia and T. rotundifolia (b) total flavonoid content as catechin equivalents quantified in the leaves of $T$. diversifolia and $T$. rotundifolia (c) flavonol content as catechin equivalents quantified in the leaves of $T$. diversifolia and $T$. rotundifolia (d) hydrolysable tannin content as gallic acid equivalents quantified in the leaves of $T$. diversifolia and T. rotundifolia. Values in bars are means \pm SEM. Sample sizes are given in parenthesis. DW =dry weight; GAE = gallic acid equivalents; $\mathrm{CE}=$ catechin equivalents

methanol extract for all strains tested, contrary to our results where we report $\mathrm{MIC}=0.6 \mathrm{mg} / \mathrm{ml}$ for $E$. coli, $E$. faecalis $S$. aureus and $1.25 \mathrm{mg} / \mathrm{ml}$ for $P$. aeruginosa (though we regard this MIC as weak). Also from their findings the chloroform extract displayed MIC of $0.78 \mathrm{mg} / \mathrm{ml}$ against $E$. faecalis and $P$. aeruginosa while our findings showed MICs of 0.31 and $0.07 \mathrm{mg} / \mathrm{ml}$ for the chloroform fraction. The inhibitory activity of the chloroform fraction against E. coli $(1.25 \mathrm{mg} / \mathrm{ml})$ compared to their study was also referred to as weak in our study. John-Dewole and Oni [31] tested activity against $S$. aureus, E. coli and $P$. aeruginosa using water and methanol extracts but only the water extract showed some activity against $S$. aureus and $E$. coli at a high concentration of $12 \mathrm{mg} / \mathrm{ml}$, while even at this concentration methanol showed no activity.

A study by Odeyemi et al. [50] also reported the inhibitory effect of the ethanol extract to E. coli, $P$. aeruginosa and Enterococcus and Salmonella species with MIC ranging from 1.25 to $5 \mathrm{mg} / \mathrm{ml}$. Essential oils from $T$. diversifolia flowers have also been reported to inhibit the growth of $E$. coli and K. pneumoniae [51]. Inhibitory activity of $E$. coli by the $90 \%$ ethanol extract with a $10.4 \mathrm{~mm}$ zone of inhibition in the disc diffusion method was reported by Anthoney et al. [52]; however, the actual concentration at which the organism was inhibited was not clearly reported.

Tithonia rotundifolia extracts and fractions displayed a broad spectrum of antibacterial activity from weak to good activity against all tested strains. The hot water extract displayed very good inhibitory activity against $E$. coli and $S$. Typhimurium and good activity against $E$. faecalis, better than the positive control gentamicin used. This was followed by the acetone extract showing good activity against $K$. pneumoniae, S. aureus and $S$. Typhimurium and very good activity against $E$. faecalis. Comparing the antibacterial activity displayed by both species, it is clear that $T$. rotundifolia extracts exhibited overall best inhibitory effect against most of the tested 


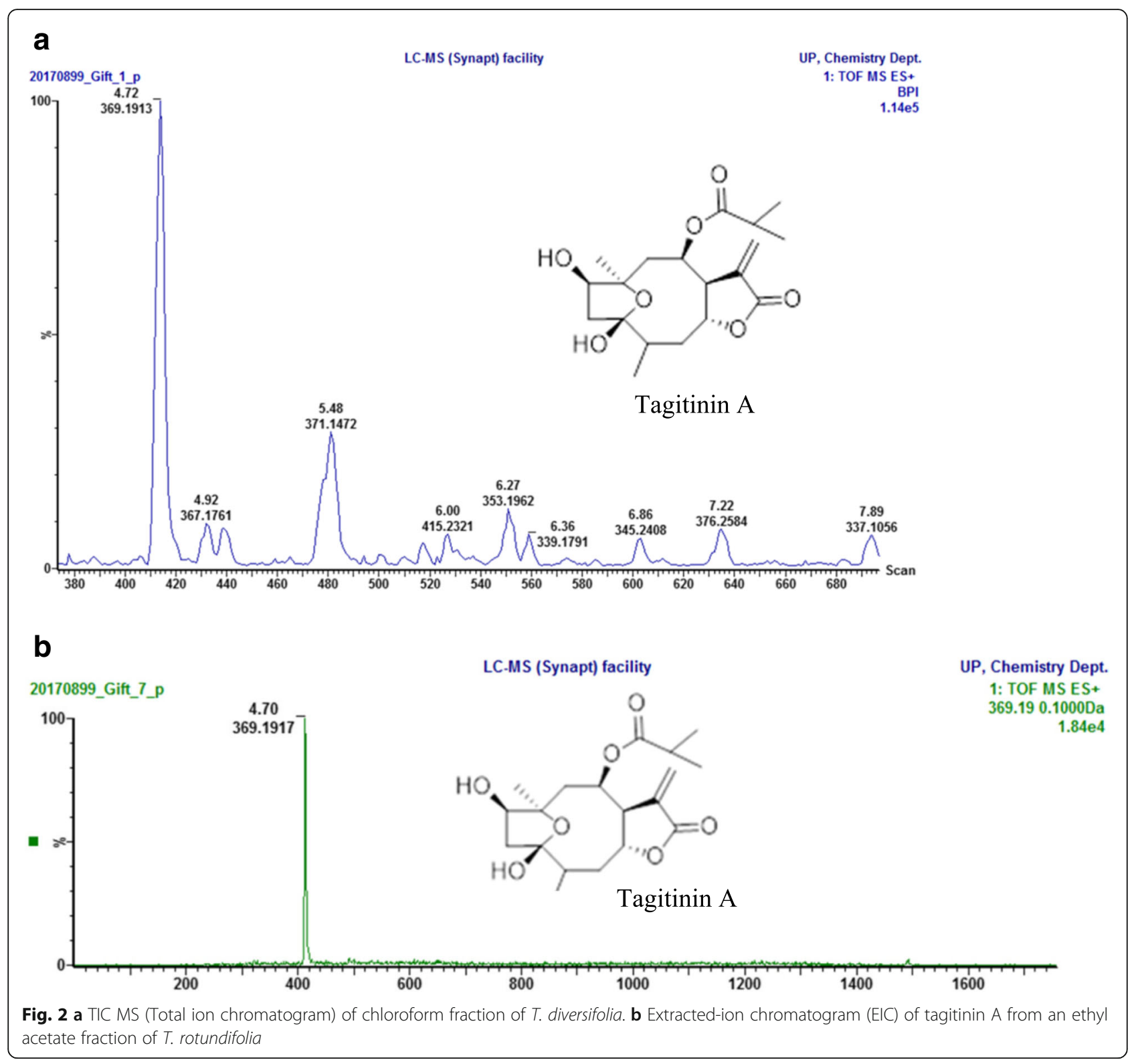

strains, while the fractions of $T$. diversifolia displayed overall better activity compared to that of $T$. rotundifolia. Although the extracts and fractions of both species showed antimycobacterial activity, the activity displayed by $T$. rotundifolia extracts and fraction (s) was better than that of $T$. diversifolia. To the best of our knowledge, this is the first time the antimycobacterial activity of these species has been reported. However, the antimycobacterial activity of other plant species in the Asteraceae family has been reported [53].

\section{Antifungal activity of extracts and fractions of $T$. diversifolia} and $T$. rotundifolia

Antifungal activity was displayed by $T$. diversifolia and $T$. rotundifolia against $A$. fumigatus, $C$. neoformans and C. albicans at 48 and $72 \mathrm{~h}$ incubation. However, there was a differential growth response by the strains tested to different extracts and solvents of the species. At $48 \mathrm{~h}$, ethanol, methanol and acetone extracts of $T$. diversifolia were very effective against $C$. neoformans, but there was a reduced activity at $72 \mathrm{~h}$ showing that the species was able to overcome the inhibitory effect to an extent. Only the hexane fraction was very effective against $C$. neoformans at 48 and $72 \mathrm{~h}$. Activity displayed by other extracts and fractions against A. fumigatus and C. albicans was moderate to weak. Although information on the antifungal screening of $T$. diversifolia against the strains used in this study is scarce, an investigation carried out by Linthoingambi and Singh 
Table $\mathbf{5} \mathrm{LC}_{50}$ values of $T$. diversifolia and $T$. rotundifolia solvent extracts against Vero Monkey kidney cells

\begin{tabular}{lll}
\hline Plant species & Extract & $\mathrm{LC}_{50}$ values $(\mathrm{mg} / \mathrm{ml})$ \\
\hline T. diversifolia & Ethanol & $0.004 \pm 0.004$ \\
& Methanol & $0.002 \pm 0.001$ \\
& DCM & $0.004 \pm 0.001$ \\
& Acetone & $0.012 \pm 0.009$ \\
& Hot water & $0.275 \pm 0.04$ \\
T. rotundifolia & Ethanol & $0.533 \pm 0.113$ \\
& Methanol & $0.518 \pm 0.211$ \\
& DCM & $0.938 \pm 0.000$ \\
& Acetone & $0.782 \pm 0.089$ \\
Doxorubicin $+\mathrm{ve}(\mu \mathrm{g} / \mathrm{ml})$ & Hot water & $0.841 \pm 0.325$ \\
& & $0.2009 \pm 0.000$
\end{tabular}

$D C M$ dichloromethane

[49] in screening chloroform and methanol extracts of $T$. diversifolia against other fungal strains confirms the antifungal activity in this study. Agboola et al. [51] reported the essential oil from $T$. diversifolia to be effective against Fusarium lateritum, F. solani and Cochliobolus lunatus, though at a very high concentration of $72 \mathrm{mg} / \mathrm{ml}$.

The DCM and acetone extracts of $T$. rotundifolia exhibited good activity against $C$. neoformans and C. albicans at MIC $0.07 \mathrm{mg} / \mathrm{ml}$, but showed moderate activity at $72 \mathrm{~h}$ for both strains. Among all extracts tested only the acetone extract of $T$. rotundifolia showed good activity against A. fumigatus at $48 \mathrm{~h}$. The fractions of $T$. rotundifolia were not as effective as the crude extracts. The results in Table 3 suggest that both species may be good antifungal agents that may be exploited as a source of antifungal treatment.

\section{Phytochemical analysis Phytochemical detection and quantification}

The phytochemicals identified in both species were phenolics, flavonoids, tannins, alkaloids and saponins. The flowers of $T$. diversifolia have been reported previously to contain phenolics, flavonoids, tannins and saponins $[54,55]$ but no alkaloids were detected. Though our results agree for phenolics, flavonoids, tannins and saponins, the absence of alkaloids in their investigation may be due to the plant part used. Our findings agree with those of John-Dewole and Oni [31] who also detected alkaloids in the leaves. Results from the phytochemical quantification (Fig. 1a-d) showed that both $T$. diversifolia and $T$. rotundifolia are rich in phenolics, flavonoids and hydrolysable tannins. Phenolics were higher in T. diversifolia and the difference was statistically significant $\left(\mathrm{t}_{2}=\right.$ 4.34; $P<0.002)$. Tithonia rotundifolia contained higher amounts of flavonoid and flavonol contents but there were no significant differences $\left(\mathrm{t}_{2},=-1.29 ; P=0.234\right)$ and $\left(\mathrm{t}_{2}=1.14 ; P=0.984\right)$. Hydrolysable tannin content was higher in $T$. rotundifolia with a statistical difference $\left(\mathrm{t}_{2}=-2.92 ; P=0.019\right)$. The antimicrobial activity displayed by both species may be attributed to the major phytochemicals quantified in this study, as they are known to be responsible for other biological activities such as anti-inflammatory, antiviral, antioxidant and wound healing properties [56-58]. Compounds such as sesquiterpenes, diterpenes, and flavonoids have been isolated from T. diversifolia and T. rotundifolia [32]. Most of the compounds that have been isolated from both species are sesquiterpene lactones which are often present in the Asteraceae family [32, 59]. Most of the bioactivities reported in $T$. diversifolia have been attributed to sesquiterpene lactones such as tagitinin $\mathrm{C}$, $1 \beta$-methoxydiversifolin and tagitinin $\mathrm{A}$ and chlorogenic

Table 6 Selectivity index of bacterial strains tested against T. diversifolia and T. rotundifolia solvent extracts

\begin{tabular}{|c|c|c|c|c|c|c|c|c|}
\hline \multirow[t]{2}{*}{ Plant species } & \multirow[t]{2}{*}{ Extract } & \multicolumn{7}{|c|}{ Selectivity index (SI) } \\
\hline & & $E C$ & Kp & Ef & SD & $\mathrm{Pa}$ & $\mathrm{Sa}$ & ST \\
\hline \multirow[t]{5}{*}{ T. diversifolia } & $\mathrm{EtOH}$ & 0.0033 & 0.0065 & 0.0571 & 0.0129 & 0.0032 & 0.0129 & 0.0065 \\
\hline & $\mathrm{MeOH}$ & 0.0032 & 0.0032 & 0.0032 & 0.0032 & 0.0016 & 0.0032 & 0.0133 \\
\hline & DCM & 0.0129 & 0.0267 & 0.0129 & 0.0129 & 0.0129 & 0.0064 & 0.0065 \\
\hline & Acetone & 0.0387 & 0.08 & 0.1714 & 0.0387 & 0.0387 & 0.0194 & 0.0387 \\
\hline & Hot water & 0.220 & 0.4436 & 0.110 & 0.220 & 0.220 & 1.8333 & 0.4435 \\
\hline \multirow[t]{5}{*}{ T. rotundifolia } & $\mathrm{EtOH}$ & 1.719 & 3.553 & 1.719 & 0.861 & 0.861 & 7.614 & 0.861 \\
\hline & $\mathrm{MeOH}$ & 0.836 & 1.671 & 0.207 & 3.453 & 0.836 & 0.836 & 1.671 \\
\hline & DCM & 1.513 & 6.253 & 6.253 & 6.253 & 3.026 & $13.4^{*}$ & 6.253 \\
\hline & Acetone & 2.523 & $11.171 *$ & $26.067^{*}$ & 2.523 & 2.523 & $11.171 *$ & $11.171^{*}$ \\
\hline & Hot water & $84.100 *$ & 1.357 & $12.014^{*}$ & 1.357 & 0.673 & 2.713 & $84.100^{*}$ \\
\hline
\end{tabular}

EtOH ethanol, $\mathrm{MeOH}$ methanol, DCM dichloromethane, Ec Escherichia coli, Kp Klebsiella pneumonia, Ef Enterococcus faecalis, SD Salmonella Dublin, Pa Pseudomonas aeruginosa, Sa Staphylococcus aureus, ST Salmonella Typhimurium

Values written in bold with asterisk are non-toxic extracts with a safe margin and good promising antibacterial agent, while those written in bold with no asterisk are extracts with a relatively safe margin 
Table 7 Selectivity index of fungal strains tested against T. diversifolia and T. rotundifolia solvent extracts

\begin{tabular}{|c|c|c|c|c|c|c|c|}
\hline \multirow[t]{3}{*}{ Plant species } & \multirow[t]{3}{*}{ Extract } & \multicolumn{6}{|c|}{ Selectivity index (SI) } \\
\hline & & \multicolumn{2}{|c|}{ A. fumigatus } & \multicolumn{2}{|c|}{ C. neoformans } & \multicolumn{2}{|c|}{ C. albicans } \\
\hline & & $48 \mathrm{~h}$ & $72 \mathrm{~h}$ & $48 \mathrm{~h}$ & $72 \mathrm{~h}$ & $48 \mathrm{~h}$ & $72 \mathrm{~h}$ \\
\hline \multirow[t]{5}{*}{ T. diversifolia } & $\mathrm{EtOH}$ & 0.0016 & 0.0032 & 0.0571 & 0.0016 & 0.0016 & 0.0016 \\
\hline & $\mathrm{MeOH}$ & 0.0032 & 0.0032 & 0.0286 & 0.0032 & 0.0008 & 0.0008 \\
\hline & DCM & 0.0064 & 0.0032 & 0.0267 & 0.0129 & 0.0016 & 0.0016 \\
\hline & Acetone & 0.080 & 0.0387 & 0.1714 & 0.08 & 0.08 & 0.0194 \\
\hline & Hot water & 0.4436 & 0.4435 & 1.8333 & 0.22 & 0.22 & 0.22 \\
\hline \multirow[t]{5}{*}{ T. rotundifolia } & $\mathrm{EtOH}$ & 0.426 & 0.426 & 3.553 & 1.666 & 0.426 & 0.426 \\
\hline & $\mathrm{MeOH}$ & 0.836 & 0.414 & 1.671 & 0.836 & 0.207 & 0.207 \\
\hline & DCM & 6.253 & 0.750 & $13.400^{*}$ & 6.253 & $13.400^{*}$ & 6.253 \\
\hline & Acetone & $11.171 *$ & 0.626 & $11.171 *$ & 5.213 & $11.171 *$ & 5.213 \\
\hline & Hot water & 0.336 & NA & 1.357 & 0.336 & NA & NA \\
\hline
\end{tabular}

EtOH ethanol, $\mathrm{MeOH}$ methanol, DCM dichloromethane, A. fumigatus Aspergillus fumigatus, C. neoformans Cryptococcus neoformans, C. albicans Candida albicans, NA not available

Values written in bold with asterisk are non-toxic extracts on a safe margin and good promising antifungal agent, while those written in bold with no asterisk are extracts with a relatively safe margin

Table 8 Genotoxicity test of T. diversifolia and T. rotundifolia using Salmonella typhimurium strains TA98 and TA100 in the absence of exogenous metabolic activation

\begin{tabular}{|c|c|c|c|c|}
\hline \multirow[t]{2}{*}{ Plant species } & \multirow{2}{*}{$\begin{array}{l}\text { Extracting } \\
\text { solvent }\end{array}$} & \multirow{2}{*}{$\begin{array}{l}\text { Dose } \\
\text { ( } \mu \mathrm{g} / \text { plate) }\end{array}$} & \multicolumn{2}{|c|}{ His + revertants plate } \\
\hline & & & TA98 & TA100 \\
\hline \multirow[t]{9}{*}{ T. diversifolia } & \multirow[t]{3}{*}{ Acetone } & 5 & $27.33 \pm 1.33$ & $125.00 \pm 1.2$ \\
\hline & & 50 & $54.67 \pm 1.20$ & $116.33 \pm 1.45$ \\
\hline & & 500 & $45.00 \pm 2.52$ & $136.00 \pm 2.0$ \\
\hline & \multirow[t]{3}{*}{ DCM } & 5 & $50.00 \pm 1.15$ & $104.33 \pm 1.20$ \\
\hline & & 50 & $51.33 \pm 1.20$ & $115.00 \pm 2.00$ \\
\hline & & 500 & $75.33 \pm 0.33$ & $117.3 \pm 0.3$ \\
\hline & \multirow[t]{3}{*}{ Hot water } & 5 & $56.00 \pm 3.00$ & $117.00 \pm 0.00$ \\
\hline & & 50 & $62.00 \pm 1.73$ & $121.33 \pm 0.58$ \\
\hline & & 500 & $63.67 \pm 2.52$ & $132.33 \pm 2.52$ \\
\hline \multirow[t]{9}{*}{ T. rotundifolia } & \multirow[t]{3}{*}{ Acetone } & 5 & $32.00 \pm 1.53$ & $122.00 \pm 1.0$ \\
\hline & & 50 & $25.00 \pm 0.58$ & $113.00 \pm 1.15$ \\
\hline & & 500 & $43.33 \pm 1.67$ & $108.67 \pm 1.20$ \\
\hline & \multirow[t]{3}{*}{ DCM } & 5 & $35.33 \pm 0.88$ & $111.33 \pm 1.76$ \\
\hline & & 50 & $29.00 \pm 2.08$ & $119.00 \pm 1.2$ \\
\hline & & 500 & $26.67 \pm 1.67$ & $122.00 \pm 1.7$ \\
\hline & \multirow[t]{3}{*}{ Hot water } & 5 & $45.00 \pm 3.06$ & $112.33 \pm 4.04$ \\
\hline & & 50 & $52.00 \pm 3.00$ & $112.00 \pm 1.73$ \\
\hline & & 500 & $59.00 \pm 1.15$ & $124.33 \pm 3.06$ \\
\hline 4NQO + ve control & & & $212.7 \pm 1.9$ & $538.7 \pm 5.900$ \\
\hline $\mathrm{H}_{2} \mathrm{O}$-ve control & & & $61.33 \pm 1.45$ & $130.00 \pm 2.5$ \\
\hline $\begin{array}{l}10 \% \text { DMSO -ve } \\
\text { control }\end{array}$ & & & $57.00 \pm 1.15$ & $125.7 \pm 1.9$ \\
\hline
\end{tabular}

DCM dichloromethane, His histidine, -ve negative control, DMSO dimethylsuphoxide, $\mathrm{H}_{2} \mathrm{O}$ water acids $[6,60]$. The antimicrobial activity displayed in this study may also be due to the presence of these compounds. The LC-MS-ESI chromatogram of the active chloroform fraction of $T$. diversifolia delivered a major compound with molecular weight at $369.19[\mathrm{M}+\mathrm{H}]^{+}$, which was identified as tagitinin A followed by tagitinin C. In addition, the EIC-MS of the ethyl acetate fractions of T. rotundifolia also showed tagitinin A (Fig. 2) as the major constituent. From our results we can assume that tagitinin A may be the major antimicrobial agent responsible for activity in both species especially in $T$. rotundifolia which displayed the overall best antimicrobial activity. However, antimicrobial evaluation of this compound from the plant species is paramount to ascertain this fact.

\section{In vitro toxicity test}

Cytotoxicity test The cytotoxicity screening of plants helps to determine the safety level at which products made from such plants may be consumed that is not harmful. From our screening, we observed that $T$. diversifolia was toxic for all the extracts tested except for the hot water extract with $\mathrm{LC}_{50}$ values greater than $1 \mathrm{mg} / \mathrm{ml}$ (Table 5) at concentrations between 0.012 to $1 \mathrm{mg} / \mathrm{ml}$. The selectivity index values for both bacterial and fungal strains were less than $1 \mathrm{mg} / \mathrm{ml}$ except for the hot water extract against $S$. aureus and $C$. neoformans which showed a moderate activity. Some extracts of $T$. rotundifolia were less toxic while others were not $\left(\mathrm{LC}_{50}\right.$ ranging from 0.518 to $0.938 \mathrm{mg} / \mathrm{ml}$ ) and had selectivity index values above 1 except for the methanol extract which showed weak activity against E. faecalis and C. albicans. The antibacterial and antifungal activities displayed by 
T. diversifolia may be due to the toxicity of the plant extracts which may have influenced their activity against the strains tested. Although we have not come across any in vitro study of $T$. diversifolia, in vivo studies have shown that the plant is toxic. Elufioye [60] tested the $70 \%$ ethanol extract of the aerial parts of $T$. diversifolia in an in vivo study on Wistar rats at doses of 400, 800 and $1600 \mathrm{mg} / \mathrm{kg}$. Between $30 \mathrm{~min}$ and $24 \mathrm{~h}$ of exposure, the extract showed both haematological and acute toxic effects on the kidney and liver. In an in vivo study carried out by Fakunle and Abatan [61], haematological changes were observed in rats administered an aqueous extract of $T$. diversifolia at doses between 100 and $200 \mathrm{mg} / \mathrm{kg}$. Another study carried out by Adebayo et al. [62] on the aqueous extract at doses of 100 and $200 \mathrm{mg} /$ $\mathrm{kg}$ administered to Wistar rats for 7 days showed that at $100 \mathrm{mg} / \mathrm{kg}$ the extract was relatively safe but at $200 \mathrm{mg} /$ $\mathrm{kg}$ the extract was toxic. Aqueous extracts administered to Wistar rats at $10 \mathrm{mg} / \mathrm{kg}$ and $100 \mathrm{mg} / \mathrm{kg}$ for 90 days were reported to be relatively safe [63]. Some of the compounds reported to be responsible for toxicity of this plant are sesquiterpene lactones and chlorogenic acids $[63,64]$. The presence of sequiterpene lactones in $T$. diversifolia may lead to kidney damage while the chlorogenic acids may result in liver injuries if the plant is not used with caution [63]. Though there are many sesquiterpenes present in $T$. diversifolia the most studied are the tagitinins which have been attributed to its pharmacological activity and these tagitinins have also been isolated from $T$. rotundifolia [32]. Although there are different classes of tagitinins such as A, B, C, D and E present in both species, tagitinin $\mathrm{C}$ has been discovered to be the main compound [65]. A further study has shown that though both species contain tagininin C, there are two other derivatives of tagitinin $C$ that are only present in $T$. diversifolia, namely tagitinin $C$ 2-methylbutyrate and $1 \beta, 2 \alpha$-epoxytagitinin $C$ [32, 65, 66]. The toxicity levels displayed by $T$. diversifolia may be connected to the presence of these two compounds; however further screening is needed to ascertain this.

Genotoxicity test According to the Ames test, a sample is considered to be mutagenic or genotoxic if the revertant colonies of the test sample double the revertant colonies of the negative control(s), or if there is a dose dependent increase in the number of colonies with the sample [67]. The genotoxicity tested carried out on the DCM, acetone and hot water extracts of $T$. diversifolia and $T$. rotundifolia against TA98 and TA100 of Salmonella strains using the Ames test did not show any genotoxic effect. Although, $T$. diversifolia was toxic as shown in our cytotoxicity result (Table 5), it was not mutagenic in the Ames test. There is a need for continuous screening of this plant to ascertain if it has a selective toxicity which may be helpful in the treatment of cancer cells as related studies have been carried out by some researchers [68-70].

\section{Conclusions}

The problem caused by alien invasive plants cannot be over emphasized as they result in loss of agricultural lands, livelihoods and biodiversity which may lead to economic burden. Results from our study have shown that weeds such as $T$. diversifolia and $T$. rotundifolia may serve as a good source of antimicrobial drugs. Other work has been done on the antibacterial and antifungal activities, phytochemistry and toxicity levels of $T$. diversifolia. However, this study is the first to: (i) evaluate the antibacterial, antimycobacterial and antifungal activities of $T$. rotundifolia, (ii) determine the phytochemicals and identify the major compound that may be responsible for such activity, and (iii) determine the cytotoxicity and genotoxicity of different extracts of the plant. This is also the first study to compare the antimicrobial activity, quantify important phytochemicals such as phenolics, flavonoids and hydrolysable tannins in both $T$. diversifolia and $T$. rotundifolia, and also the cytotoxicity and genotoxicity levels of the different solvent extracts. The UPLC/MS analysis identified tagitinin $\mathrm{A}$ as a major constituent of active fractions of both plants. Our study is the first to screen these plants for genotoxicity. Though both species showed good antimicrobial activity, $T$. rotundifolia displayed a broader spectrum of antimicrobial activity. The low toxicity level displayed by $T$. rotundifolia extracts qualifies the plant for more biological screening of the extracts and compounds and also to determine the mechanism of action. This may lead to the production of novel antimicrobial drugs from this plant that may be used for the treatment of microbial infection and other opportunistic pathogenic infections in humans and animals. The economic burden caused by both species may be tackled through their use as a source of medicines. The weed plants may also serve as alternatives to highly exploited indigenous plants that possess the same medicinal properties. However, care must be taken in the use of $T$. diversifolia as it may be toxic.

\section{Abbreviations}

4-NQO: 4-nitroquinoline-N-oxide; $\mathrm{AlCl}_{3}$ : Aluminium chloride; butanol$\mathrm{HCl}$ : Butanol-hydrochloride; $\mathrm{CE}$ : Catechin equivalents; $\mathrm{CH}_{3} \mathrm{COONa}$ : Sodium ethanoate; $\mathrm{CO}_{2}$ : Carbon dioxide; DMSO: Dimethylsuphoxide; GAE: Gallic acid equivalents; $\mathrm{HCl}$ : Hydrochloric acid; HPLC-HR-ESI-MS: High Performance Liquid Chromatography- High Resolution-Electrospray lonization-Mass Spectrometry; INT: p-iodonitrotetrazolium chloride; LC $_{50}$ : Lethal concentration; MEM: Minimal Essential Medium; MIC: Minimum inhibitory concentration; $\mathrm{NaCO}_{3}$ : Sodium carbonate; OADC: oleic acid, albumin, dextrose, and catalase; 
PBS: Phosphate buffer saline; QTOF: Quadrupole-time-of-flight; UPLC: Ultra Performance Liquid Chromatography

\section{Acknowledgements}

Omokhua AG is most grateful to the National Research Foundation-The World Academy of Science (NRF-TWAS) for the provision of a grant. Many thanks to Kethani Mawela, Ms. Lynnet Khumalo, Drs. David Simelane and Costas Zachariades of the ARC-Plant Protection Institute South Africa who assisted with the collection of T. diversifolia and useful discussions that led to the investigation of these plant species. The National Research Foundation (NRF, South Africa) is acknowledged for providing research funding.

\section{Funding}

The National Research Foundation, South Africa provided research funding. The funding body had no role in the design of the study or interpretation of the results.

\section{Availability of data and materials}

All dataset and materials are available from the authors upon reasonable request.

\section{Authors' contributions}

AGO performed the experiments and wrote the first draft of the manuscript. MAA assisted with LC-MS analysis. MAA, JVS and LJM supervised the work and all authors revised the final manuscript. All authors read and approved the final manuscript.

\section{Ethics approval and consent to participate}

Not applicable.

\section{Consent for publication}

Not applicable

\section{Competing interests}

The authors declare that they have no competing interests.

\section{Publisher's Note}

Springer Nature remains neutral with regard to jurisdictional claims in published maps and institutional affiliations.

\section{Author details}

'Phytomedicine Programme, Department of Paraclinical Sciences, University of Pretoria, Private Bag X04, Onderstepoort 0110, South Africa. ${ }^{2}$ Research Centre for Plant Growth and Development, School of Life Sciences, University of KwaZulu-Natal, Private Bag X01, Scottsville 3201, South Africa. ${ }^{3}$ Deparment of Food Science and Technology, Faculty of Agriculture, University of Khartoum, 13314 Khartoum North, Sudan.

\section{Received: 23 November 2017 Accepted: 24 September 2018}

\section{Published online: 03 October 2018}

\section{References}

1. Royal Kenya Horticultural Society. Gardening in East Africa. In: Jex-Blake AJ, editor. A practical handbook. 4th ed: Longmans, Green and Co. London; 1957.

2. Arias J, Martin ME, Gimenez MJ. Chemical control on new weed in northern Argentina Tithonia tubaeformis (Jacq). Maleza II. 1982:177-81.

3. Morales E. Estimating phylogenetic inertia in Tithonia (Asteraceae): a comparative approach. Evolution. 2000;54:475-84.

4. Meyer JY. Preliminary review of the invasive plants in the Pacific Islands (SPREP member countries). In: Sherley G, editor. Invasive species in the Pacific: a technical review and draft regional strategy. Apia: South Pacific Regional Environment Programme; 2000. p. 85-114.

5. Henderson L. Comparison of invasive plants in Southern Africa originating from Southern temperate, Northern temperate and tropical regions. Bothalia. 2006;36(2):201-22

6. Goffin E, Ziemons E, Mol P, Madureira MC, Martins AP, Cunha AP, Philippe $G$, Tits $M$, Angenot $L$, Frédérich $M$. In vitro antiplasmodial activity of Tithonia diversifolia and identification of its main active constituent: Tagitinin C. Planta Med. 2002;68(6):543-5.
7. Muoghalu J, Chuba DK. Seed germination and reproductive strategies of Tithonia diversifolia (Hemsl.) gray and Tithonia rotundifolia (P.M) Blake. Appl Ecol Environ Res. 2005;3(1):39-6.

8. Akobundu 10, Agyakwa CW. A handbook of West African Weeds. 1st ed. Ibadan: International Institute of Tropical Agriculture; 1987. p. 521.

9. Simelane DO, Mawela KV, Fourie A. Prospective agents for the biological control of Tithonia rotundifolia (Mill.) S.F. Blake and Tithonia diversifolia (Hemsl.) a. gray (Asteraceae) in South Africa. Afr Entomol. 2011;19(2):443-50.

10. Henderson L. Alien weeds and invasive plants. Plant Prot Res Inst Handb. 2001;12:p77.

11. National Environmental Management: Biodiversity Act (NEMBA), Act No. 10 of 2004, Alien and Invasive Species List. Department of Environmental Affairs; 2016. p. 60

12. Játem-Lásser A, Mario SR, Giusseppe A. Herbal traditional medicine of Venezuelan Andes: an ethnopharmacological study. Phytother Res. 1998; 12:53-9.

13. Heinrich M, Robles M, West JE, de Montellano OBR, Rodriguez E. Ethnopharmacology of Mexican Asteraceae (Compositae). Annu Rev Pharmacol Toxicol. 1998;38:539-65.

14. Frei B, Baltisberger M, Sticher O, Heinrich M. Medical ethnobotany of the Zapotecs of the isthmus-sierra (Oaxaca, Mexico): documentation and assessment of indigenous uses. J Ethnopharmacol. 1998;62(2):149-65.

15. Heinrich M. Ethnobotany and its role in drug development. Phytother Res 2000;14(7):479-88

16. Miura T, Nosaka K, Ishii H, Ishida T. Antidiabetic effect of Nitobegiku, the herb Tithonia diversifolia, in KK-Ay diabetic mice. Biol Pharm Bull. 2005;28: 2152-4

17. Njoroge GN, Bussmann RW. Herbal usage and informant consensus in Ethnoveterinary management of cattle diseases among the Kikuyus (Central Kenya). J Ethnopharmacol. 2006;108:332-9.

18. Kamatenesi-Mugisha M, Oryem-Origa H, Odyek O, Makawiti DW. Medicinal plants used in the treatment of fungal and bacterial infections in and around queen Elizabeth biosphere reserve, Western Uganda. Afr J Ecol. 2008;46:90-7.

19. Afolayan FID, Adegbolagun OM, Irungu B, Kangethe L, Orwa J, Anumudu C. Antimalarial actions of Lawsonia inermis, Tithonia diversifolia and Chromolaena odorata in combination. J Ethnopharmacol. 2016;191:188-94.

20. Jama B, Palm C, Buresh R, Niang A, Gachengo C, Nziguheba G, Amadala B. Tithonia diversifolia as a green manure for soil fertility improvement in Western Kenya: a review. Agrofor Syst. 2000;49:201-21.

21. Adeniyan $\mathrm{OB}$, Ojeniyi SO, Akinola MO. Effect of weed mulch on soil properties, growth tuber yield and nutrient content of Yam (Dioscored rotundata poir.). Int J Agr Sci. 2008;2:70-4.

22. Mwine J, Van Damme P, Kamoga G, Kudamba NM, Jumba F. Ethnobotanical survey of pesticidal plants used in South Uganda: case study of Masaka district. J Med Plant Res. 2011:5(7):1155-63.

23. Ojeniyi SO, Odedina SA, Agbede TM. Soil productivity improving attributes of Mexican sunflower (Tithonia diversifolia) and siam weed (Chromolaena odorata). Emir J Food Agric. 2012;24:243-7.

24. Tona L, Kambu K, Ngimbi N, Cimanga K, Vlietinck AJ. Antiamoebic and phytochemical screening of some Congolese medicinal plants. J Ethnopharmacol. 1998:61(1):57-65.

25. Chiang LC, Cheng HY, Chen CC, Lin CC. In-vitro anti-leukemic and antivira activities of traditionally used medicinal plants in Taiwan. Am J Chin Med. 2004;32(5):695-704.

26. Ragasa C, Tepora MM, Rideout JA. A triterpene from Rosa sp. IJSRSET. 2007:4:1-5.

27. Oyewole IO, Ibidapo CA, Moronkola DO, Oduola AO, Adeoye GO, Anyasor GN, Obansa JA. Anti-malarial and repellent activities of Tithonia diversifolia (Hemsl.) leaf extracts. J Med Plant Res. 2008;2(8):171-5.

28. Ahmed S, Onocha AP. Antiemetic Activity of Tithonia diversifolia (HemsL) A Gray leaves in copper sulphate induced chick emesis model. Am J Phytomed Clin Therapeut. 2013;1:734-9.

29. Thongsom M, Chunglok W, Kuanchuea R, Tangpong J. Antioxidant and hypoglycaemic effects of Tithonia diversifolia aqueous leaves extract in alloxan-induced diabetic mice. Adv Environ Biol. 2013;7(9): 2116-25.

30. Obafemi CA, Sulaimon TO, Akipelu DA, Olugbade TA. Antimicrobial activity of extracts and a germacranolide-type sesquiterpene lactone from Tithonia diversifolia leaf extract. Afr J Biotechnol. 2006;5(12):1254-8. 
31. John-Dewole OO, Oni SO. Phytochemical and antimicrobial studies of extracts from the leaves of Tithonia diversifolia for pharmaceutical importance. Int J Pharm Bio Sci. 2013;6:21-5.

32. Chagas-Paula DA, Oliveira RB, Rocha BA, da Costa FB. Ethnobotany, chemistry, and biological activities of the genus Tithonia (Asteraceae). Chem Biodivers. 2012;9:210-35.

33. Elisha IL, Jambalang AR, Botha FS, Buys EM, McGaw L, Eloff JN. Potency and selectivity indices of acetone leaf extracts of nine selected South African trees against six opportunistic Enterobacteriaceae isolates from commercial chicken eggs. BMC Complement Altern Med. 2017;17(90):1-8.

34. McGaw LJ, Lall N, Hlokwe TM, Michel A, Meyer JJM, Eloff JN. Purified compounds and extracts from Euclea species with antimycobacterial activity against Mycobacterium bovis and fast-growing mycobacteria. Biol Pharm Bull. 2008;31:1429-33.

35. Eloff JN. A sensitive and quick microplate method to determine the minimal inhibitory concentration of plant extracts for bacteria. Planta Med. 1998;64(8):711-3.

36. Masoko P, Picard J, Eloff JN. The antifungal activity of twenty four southern African Combretum species (Combretaceae). S Afr J Bot. 2007;73(2):173-83.

37. Trease GE, Evans WC. Testbook of PhDarmacognosy. 12th ed. London: Balliese Tindall and Company Publisher; 1983. p. p343-83.

38. Trease GE, Evans WC. Textbook of Pharmacognosy. 15th ed. London: Saunders Publishers; 2002. p. 42-4. 391-3

39. Sofowora EA. Medicinal Plants and Traditional Medicines in Africa. New York: Willey and Sons; 1993.

40. Makkar HPS, Siddhuraju P, Becker K. Plant secondary metabolites. In: Humana Press; 2007

41. Tadhani M, Subhash R. Preliminary studies on Stevia rebaudiana leaves: proximal composition, mineral analysis and phytochemical screening. J Med Sci. 2006;6(3):321-6.

42. Makkar HPS. Quantification of tannins in tree and foliage- a laboratory manual. Vienna: FAO/IAEA; 2003.

43. Abdel-Hameed ESS. Total phenolic contents and free radical scavenging activity of certain Egyptian Ficus species leaf samples. Food Chem. 2009; 114(4):1271-7.

44. Mosmann T. Rapid colorimetric assay for cellular growth and survival: application to proliferation and cytotoxicity assays. J Immunol Methods. 1983;65(1-2):55-63.

45. Freire PF, Peropadre A, Pérez Martín JM, Herrero O, Hazen MJ. An integrated cellular model to evaluate cytotoxic effects in mammalian cell lines. Toxicol in Vitro. 2009;23:1553-8.

46. Maron DM, Ames BN. Revised methods for the Salmonella test. Mutat Res. 1983;113:173-215.

47. Eloff JN. Quantifying the bioactivity of plant extracts during screening and bioassay-guided fractionation. Phytomedicine. 2004;11:370-1.

48. Sánchez JGB, Kouznetsov V. Antimycobacterial susceptibility testing methods for natural products research. Braz J Microbiol. 2010;41:270-7.

49. Linthoingambi W, Singh WS. Antimicrobial activities of different solvent extracts of Tithonia diversifolia (Hemsely) A. Gray. Asian J Plant Sci Res. 2013;3:50-4

50. Odeyemi AT, Agidigbi TS, Adefemi SO, Fasuan SO. Antibacterial activities of crude extracts of Tithonia diversifolia against common environmental pathogenic bacteria. Experiment. 2014;20(4):1421-6.

51. Agboola OO, Stephen O, Olowooyo JO, Ajao AA, Aregbesola O. Chemical composition and antimicrobial activities of essential oil extracted from Tithonia diversifolia (Asteraceae) flower. J Biores Bioprod. 2016;1:169-76.

52. Anthoney ST, Jackie OK, Miyogo E, Lasiti TT. Bioassay screening of the ethanolic extract of Tithonia diversifolia leaves on selected microorganisms. Int J Bioass. 2016:5:4794-8.

53. Robles-Zepeda RE, Coronado-Aceves EW, Velázquez-Contreras CA, RuizBustos E, Navarro-Navarro M, Garibay-Escobar A. In vitro anti-mycobacterial activity of nine medicinal plants used by ethnic groups in Sonora, Mexico. BMC Complement Altern Med. 2013;13:329.

54. Essiett UA, Akpan EM. Proximate composition and phytochemical constituents of Aspilia africana (Pers) C.D. Adams and Tithonia diversifolia (Hemsl) a. gray stems (Asteraceae). Bull Env Pharmacol Life Sci. 2013;2(4):33-7.

55. da Gama RM, Guimarães M, de Abreu LC, Armando-Junior J. Phytochemical screening and antioxidant activity of ethanol extract of Tithonia diversifolia (Hemsl) a. gray dry flowers. Asian Pac J Trop Biomed. 2014;4:740-2.
56. Agrawal B, Das S, Pandey A. Boerhaavia diffusa Linn:: a review on its phytochemicals and pharmacological profile. Asian J Appl Sci. 2011:1-22.

57. Amjad L, Shafighi M. Evaluation of antioxidant activity, phenolic and flavonoid content in Punica granatum var. Isfahan Malas flowers. Intl J Agri Crop Sci. 2013;5(10):1133-9.

58. Kumar S, Pandey AK. Chemistry and biological activities of flavonoids: an overview. Sci World J. 2013;2013:p16.

59. Ali MS, Ibrahim SA, Ahmed S, Lobkovsky E. Guaiane Sesquiterpene Lactones from Salvia nubicola (Lamiaceae). Chem Biodivers. 2007:4:98-104.

60. Passoni FD, Oliveira RB, Chagas-Paula DA, Gobbo-Neto L, da Costa FB. Repeated-Dose toxicological studies of Tithonia diversifolia (Hemsl.) A. Gray and identification of the toxic compounds. J Ethnopharmacol. 2013;147(2): 389-94.

61. Elufioye TO, Alatise OI, Fakoya FA, Agbedahunsi JM, Houghton PJ. Toxicity studies of Tithonia diversifolia A. Gray (Asteraceae) in rats. J Ethnopharmacol. 2009;122(2):410-5

62. Fankule JO, Abatan MO. The toxicological effects of aqueous extract of Tithonia diversifolia gray in rats. Asian J Anim Vet Adv. 2007:6(10):1223-6.

63. Adebayo JO, Balogun EA, Oyeleke SA. Toxicity study of the aqueous extract of Tithonia diversifolia leaves using selected biochemical parameters in rats. Pharm Res. 2009;1(3):143-7.

64. Schmidt TJ. Toxic activities of sesquiterpene lactones: structural and biochemical aspects. Curr Org Chem. 1999;3(6):577-608.

65. Ambrósio SR, Oki Y, Heleno VCG, Chaves JS, Nascimento PGBD, Lichston JE, Constantino MG, Varanda EM, Da Costa FB. Constituents of glandular trichomes of Tithonia diversifolia: relationships to herbivory and antifeedant activitytrichomes of Tithonia diversifolia: relationships to herbivory and antifeedant activity. Phytochemistry. 2008;69(10):2052-60.

66. Gu J, Gills JJ, Park EJ, Mata-Greenwood E, Hawthorne ME, Axelrod F, Chavez $\mathrm{PI}$, Fong HHS, Mehta RG, Pezzuto JM, Kinghorn AD. Sesquiterpenoids from Tithonia diversifolia with potential cancer chemopreventive activity. J Nat Prod. 2002;65(4):532-6.

67. Verschaeve L, Van Staden J. Mutagenic and antimutagenic properties of extracts from south African traditional medicinal plants. J Ethnopharmacol. 2008;119(3):575-87.

68. Wu TS, Shi LS, Kuo PC, Leu YL, Liou MJ, Wu PL, Wu YC, lou SC, Chen YP, Chang HC. Cytotoxic principles from the leaves of Tithonia diversifolia. Chin Pharm J. 2001;53:217-23.

69. Kuroda M, Yokosuka A, Kobayashi R, Jitsuno M, Kando H, Nosaka K. Sesquiterpenoids and flavonoids from the aerial parts of Tithonia diversifolia and their phytotoxic activity. Chem Pharm Bull. 2007;55:1240-4.

70. Sashita Y, Mimaki Y, Kuroda A, Kobayashi R, Shindo H, Nosaka K, Ishii H, Yamori T. Patent application publication, US 2007/0129427 A1 2007.

Ready to submit your research? Choose BMC and benefit from:

- fast, convenient online submission

- thorough peer review by experienced researchers in your field

- rapid publication on acceptance

- support for research data, including large and complex data types

- gold Open Access which fosters wider collaboration and increased citations

- maximum visibility for your research: over $100 \mathrm{M}$ website views per year

At BMC, research is always in progress.

Learn more biomedcentral.com/submissions 